\title{
Ideološki vidiki razmerja med (demokratično) politiko in pravom
}

UDK: $3542.31: 321.7$

\section{Miro Cerar}

Pravna fakulteta, Univerza v Ljubljani

miro.cerar@pf.uni-lj.si

\section{IZVLEČEK}

Pojem ideologije ima kljub različnim opredelitvam nekatere skupne imenovalce, med katere sodijo predvsem primarno politični pomen ideologije, njena deskriptivno-preskriptivna narava, akcijska in vrednostno-ciljna usmerjenost, usmerjenost $k$ ljudskim množicam, poenostavljenost, shematičnost ter predstavitev v motivacijskem duhu. Tudi demokratična politika in pravo sta ideološko pogojena, pri čemer je pravo na eni strani izraz in sredstvo oblastne ideologije, na drugi strani pa tudi izraz avtonomne pravne ideologije, ki postavlja določene meje politični ideologiji. Ideologijo prava oziroma pravne države na eni strani vzpostavljajo oziroma instrumentalizirajo politični akterji, na drugi strani pa tudi pravni akterji (predvsem iz poklicnih slojev pravnikov). $V$ obeh primerih se je treba izogibati vrednostno negativni oziroma družbeno destruktivni ideologizaciji prava in pravne države, ki spodbuja $v$ javnosti bodisi precenjevanje bodisi podcenjevanje vloge in pomena prava $v$ družbi. Še posebej pa se je treba izogibati takšni ideologizaciji prava, ki se kaže v politizaciji pravne stroke in pravnih (npr. pravosodnih) institucij.

\section{Ključne besede: pravo, politika, demokracija, ideologija}

\section{Pojem ideologije}

Beseda ideologija izvira iz obdobja devetdesetih let 18. stoletja, in sicer iz post-revolucionarne Francije. Čeprav se pojem ideologija od takrat do danes $\vee$ politološki in širši družbeni teoriji opredeljuje na različne, včasih tudi medsebojno izključujoče se načine, obstaja $\vee$ teoriji relativno visoka stopnja soglasja o tem, da je avtor tega pojma francoski plemič, učenjak ter predstavnik takratne filozofije materialistov Antoine Luis Claude Destutt de Tracy (1754-1836) (Manning, 1980, str. 1-2; Baradat, 1997, str. 6; Drucker, 1974, str. 3-4). De Tracy je med letoma 1796 in 1798, v okviru svojega sistematičnega preučevanja razsvetljenstva, ta pojem skoval z željo, da bi z njim povsem jasno 
Miro Cerar

Ideološki vidiki razmerja med

(demokratično) politiko in pravom

označil oziroma poimenoval novo znanost, tj. "znanost o idejah ", znanost, v okviru katere se ideje oblikujejo s pomočjo znanja, ki temelji na podlagi izkustvenega (empiričnega) preučevanja, ne pa na nadnaravnih ali duhovnih pojavih.

Ideologija kot nova znanost je torej $\vee$ tem svojem izvornem pomenu otrok moderne dobe, dobe "razsvetljenega (raz)uma", ki se zoperstavlja starim (srednjeveškim itd.) verskim in drugačnim dogmam in zavrača vsako metafiziko ter postavlja $\vee$ ospredje človekovo racionalno sposobnost odkrivanja zakonitosti (družbenega) sveta. Vendar pa se že $\vee$ okviru t.i. klasične uporabe pojma ideologije, kot je npr. značilna za de Tracyja, Marxa in Mannheima (Manning, 1980, str. 6-11), kažejo bistvene razlike prav glede ocene, ali je ideologija lahko objektivna. Tako na eni strani de Tracy kot bistveno komponento ideologije izpostavlja predvsem znanstvenost $v$ smislu racionalne preverljivosti in objektivnosti družboslovnega preučevanja in usmerjanja, pri čemer naj bi bila ideologija sposobna iznajti ustrezna "zdravila" za pomanjkljivosti družbe ter jo voditi v blagostanje. Na drugi strani pa Marx in Mannheim, seveda vsak s svoje družboslovne oziroma filozofske pozicije, ideologijo označujeta (in obsojata) predvsem kot nekaj partikularnega in subjektivnega, saj naj bi se pripadnik ideologije pri svojem delovanju $\vee$ svetu ne mogel izogniti lastni pristranskosti (Manning, 1980, str. 6-7). Prav iz takšnega pogleda, ki se zaveda neizogibnega vpliva človekove subjektivnosti na lastna dojemanja in ravnanja ter na družbeno dogajanje kot takšno, pa seveda sledi, da ideologija ne more biti zgolj ena (kot je to menil de Tracy), pač pa lahko nosi vsaka relativno zaokrožena družbena usmeritev oziroma "teorija " $\checkmark$ sebi tudi določeno ideologijo. To je povsem samoumevno tudi $v$ sodobnih opredelitvah pojma ideologije, ki se sicer, kot rečeno, $v$ marsičem razlikujejo, vendar pa ob iskanju skupnih imenovalcev oziroma bistvenih značilnosti tega pojma implicitno in eksplicitno priznavajo oziroma izpostavljajo obstoj različnih ideologij. Pojem ideologije, ki je prvotno pomenil »individualno oznako«, je tako v razvoju družbene misli prevzel "generičen pomen «.

Če z ideologijo na splošno poimenujemo specifičen sklop povezanih oziroma soodvisnih konceptov, vrednot in simbolov, ki na eni strani kritično odsevajo oziroma interpretirajo preteklo in obstoječo družbeno situacijo (deskriptivni vidik) ter hkrati določajo, h katerim vrednotam in ciljem naj se družba usmeri v prihodnje (preskriptivni vidik) (Vincent, 1995, str. 16), potem lahko ugotovimo, da so se $v$ zgodovini različni zametki oziroma nastavki ideologij pojavljali že zdavnaj pred obdobjem evropskega razsvetljenstva. Če bi npr. s pojmom ideologije lahko zajeli tudi starodavne religije in njihove temeljne "duhovno - idejne« razlage in vodila, potem bi seveda lahko rekli, da je novoveški pojem ideologije le zapoznela oznaka za že uveljavljene družbene idejne sisteme in prakse. Vendar pa ideologij in religij $\vee$ nekaterih bistvenih prvinah ni mogoče enačiti. Pri tem niti ni nujno, da izhajamo zgolj iz izvorne oziroma klasične de 


\section{Miro Cerar \\ Ideološki vidiki razmerja med (demokratično) politiko in pravom}

Tracy-jeve opredelitve ideologije kot sekularne družbene znanosti, kajti v sodobni teoriji se izpostavljajo tudi druge razlike med religioznim in ideološkim, kot so npr. odsotnost religiozne kategorije večnosti v ideoloških spisih ali pa razlike $v$ motivih pri religioznih ritualih na eni strani in ideoloških ritualih na drugi (Grimes, 1980, str. 34, 35-36). Na razliko med ideologijo in religijo med drugim posredno kaže tudi ugotovitev, da je mogoče o pojmu ideologije dejansko govoriti šele na tisti točki zgodovinskega razvoja, ko so se sistemi idej prvič soočili z zavestjo o svoji partikularnosti, kar se je dejansko zgodilo šele $v$ času razvoja meščanske družbe, $v$ kateri so se idejni sistemi morali soočiti s tujimi ali alternativnimi oblikami diskurza ter tako pristati na pluralnost idej ter na dejstvo, da se družba nenehno spreminja (Eagleton, 1994, str. 192). Prav tako pa je na tem mestu treba tudi opozoriti, da ideologij $\vee$ ožjem smislu ni mogoče enačiti s političnimi teorijami ali filozofijami, kajti $\vee$ primerjavi s slednjimi so ideologije mnogo manj natančne, sistematične in kompleksne, pri čemer pa vsaka ideologija praviloma iz politične teorije ali filozofije črpa podlago za svoje ideje (Macpherson, 1973, str. 158).

Ne da bi se globlje spuščali $v$ razmerje ideologije do drugih sorodnih pojavnosti oziroma področij, velja v okviru in za namen tega prispevka ugotoviti, da se ideologija $v$ politološki znanosti opredeljuje kot relativno samostojna pojavnost, glede katere obstoje sicer številne različne definicije, ki pa jih je le mogoče združiti na določenih skupnih imenovalcih. Med takšne skupne imenovalce lahko uvrstimo predvsem naslednje:

1. Če ni izrecno izpostavljeno drugače, ima pojem ideologije političen pomen.

2. Vsaka ideologija vsebuje interpretacijo sedanjosti in pogled na zaželeno prihodnost. Pri tem je anticipirana prihodnost vedno prikazana kot materialno boljša od sedanjosti in pogosto tudi tako, kot da jo je mogoče doseči v času enega človeškega življenja.

3. Vsaka ideologija je akcijsko usmerjena in vključuje $v$ ta namen seznam določenih dejanj, ki jih je treba storiti, da bi dosegli njene cilje.

4. Ideologije so vedno usmerjene $\mathrm{k}$ ljudskim množicam.

5. Ideologije so izražene na preprost in shematičen način ter so predstavljene v motivacijskem duhu.

Dandanes so torej ideologije razumljene predvsem kot politični pozivi ljudskim množicam, da (naj) le-te delujejo na določen način in za dosego določenih ciljev, ki pomenijo (točneje: naj bi pomenili) izboljšanje političnega življenja. Ideologije so nujne za kakršnokoli učinkovito politično gibanje, pri čemer velja iz okvira zgoraj navedenih ugotovitev posebej izpostaviti predvsem njihovo trojno funkcijo: a) poenostavitev interpretacij sedanjosti in projekcij prihodnosti; 
Miro Cerar

Ideološki vidiki razmerja med

(demokratično) politiko in pravom

b) postavljanje zahtev po določenem delovanju ter c) utemeljevanje oziroma opravičevanje takšnih zahtev. Ob vsem tem velja na tem mestu še poudariti, da lahko o obstoju politične ideologije govorimo le takrat, kadar se določena politika usmerja oziroma vodi pretežno na podlagi intelektualnih in ne zgolj spontanih, naključnih impulzov (random impulses). Na ta način se kaže poučevalni oziroma mnenjski značaj (doxic character) ideologije, ki se ubeseduje $v$ obliki različnih življenjskih vodil (maksim), gesel (sloganov) in drugih lapidarnih formul ter se na ta način močno približuje retoriki (Ricoeur, 1981, str. 226)

\section{Ideologija in demokracija}

V okviru sodobnih držav ter na ravni njihovega sodelovanja in povezovanja praktično nobena dolgoročneje zastavljena in institucionalizirana politika ni (več) brez ideološke podlage. Seveda obstajajo tudi drugačna razmišljanja, ki izpostavljajo neideološkost določenih oblik političnega sistema. Tako je npr. lahko na prvi pogled prepričljiva ugotovitev, da je ideološka izoblikovanost značilna predvsem za nedemokratične državne ureditve, ki snujejo takšne ali drugačne (utopične) podobe prihodnje družbe, pri čemer naj bi bila tudi znotraj te kategorije ureditev razvita ideologija prisotna le $v$ totalitarnih ureditvah (nacizem, fašizem, komunizem itd.), medtem ko naj bi bila za avtoritarne ureditve značilna odsotnost vodilne ideologije, za tradicionalne ureditve pa naj bi veljalo, da izdelanih ideologij sploh ne poznajo (Della Porta, 2003, str. 50-52). Vendar pa bi bila takšna ugotovitev, če bi jo prenesli tudi na moderne oblike demokracije (če se tu omejimo le na to vrsto političnega sistema), bodisi naivna ali pa celo namenoma zavajajoča ( $v$ slednjem primeru tudi ideološka).

Podmena, da sodobna demokracija nima vodilnega, to je prevladujočega ideološkega temelja, je zmotna, kajti tudi (ta) demokracija je $v$ takšni ali drugačni obliki zasnovana na določeni skupni, enotni in prevladujoči ideološki podlagi ( $v$ tem pogledu delita $z$ njo usodo tudi njena politika in pravo), ki pa se ne manifestira isti način in $v$ isti meri kot to velja za ideologije različnih »revolucionarno" usmerjenih nedemokratičnih družb. Ideologija sodobnega zahodnega tipa demokracije se $\vee$ pretežni meri ne izraža $\vee$ koncentrirani obliki, npr. na rednih in "obveznih « javnih političnih shodih, v vsakodnevnih javnih političnih razglasih, $v$ obliki udarnih ideoloških gesel in pozivov na takšno ali drugačno skupno akcijo ipd. Demokratična ideologija se $v$ svojih skupnih imenovalcih $v$ pretežni meri manifestira razpršeno in kot takšna tudi manj transparentno od nedemokratične ideologije. Seveda pa je $v$ sodobni informacijski družbi tudi kot takšna zelo prodorna, saj po eni strani prek različnih informacijskih medijev in izobraževalnih institucij doseže skorajda vsakogar, po drugi strani pa kot razpršena 


\section{Miro Cerar \\ Ideološki vidiki razmerja med (demokratično) politiko in pravom}

$\checkmark$ ljudeh ne zbuja občutka, da so pod ideološkim vplivom ali pritiskom (ljudje torej vsaj v večji meri nimajo občutka, da jih kdo v kaj ideološko prisiljuje, oziroma da jim kdo "pere možgane - čeprav se to seveda v vsaki ureditvi, tudi demokratični, vseskozi dogaja). Tako se npr. pretežno liberalistične postavke o naravni prirojenosti človekovih svoboščin in pravic slehernemu posamezniku, o ljudskem izvoru državne oblasti ali o svobodni gospodarski pobudi in o ključnem pomenu zasebne lastnine vsakodnevno ukoreninjajo $v$ ljudi z navidez preprostimi oblikami medijsko podprte propagande (politične retorike, ekonomske propagande, sporočil izobraževalnega sistema in mnenjskih voditeljev itd.).

To, kar daje demokraciji kljub vsemu temu videz neideološkosti, je navidezna odsotnost strnjenih in homogenih akcijskih, motivacijskih in ciljnih idejnih impulzov. Demokracija se površinsko kaže in pogosto tudi namenoma, ideološko zavajajoče predstavlja le kot ideološko nevtralen in pluralen prostor, ki omogoča veliko prostora različnim političnim in drugim idejnim usmeritvam. Vendar pa pri tem nobena posamezna ideologija $v$ najširšem smislu besede ne sme preseči mejá svoje partikularnosti, kajti to bi pomenilo ukinitev krovne, univerzalne demokratične ideologije. Demokratična ideologija torej znotraj svojega vrednostnega in akcijskega prostora dopušča politično - ideološki (in s tem tudi vrednostni) pluralizem in kompetitivnost, vendar pa hkrati (po potrebi tudi s prisilnimi sredstvi) zagotavlja, da se navedeni pluralizem in kompetitivnost manifestirata zgolj $v$ določenih demokratičnih ideoloških okvirih. Če so le-ti za daljši čas ali trajno prekoračeni oziroma zanikani, potem to pomeni, da je neka druga ideologija (in posledično politika) prevladala nad demokratično ideologijo, čemur sledi vzpostavitev novega, npr. avtokratskega političnega sistema. Prej omenjene akcijska, motivacijska in ciljna komponenta demokratične ideologije se zato kažejo (seveda na omenjeni razpršeni in zato manj očitno opazni način) predvsem $v$ težnji po uveljavljanju temeljnih sestavin (načel, pravil in praks) demokratičnega političnega sistema ter $\vee$ težnji po njihovem vrednostno pozitivnem spreminjanju znotraj teh okvirov. $\vee$ trenutku, ko je demokracija resno ogrožena, pa se seveda navedene tri ideološke komponente, ki jih spodbujajo demokratične elite, politično izrazijo strnjeno, eksplicitno in intenzivno, pri čemer je za uspešno obrambo demokracije ključno, koliko moči takrat te elite še premorejo oziroma jo lahko aktivirajo.

Rejai $(1967$, str. 42, 46) ugotavlja, da je velik del literature o demokraciji po naravi ideološki, pri čemer imajo ideološko naravo še posebej normativne prvine $\vee$ različnih opredelitvah demokracije (po mnenju navedenega avtorja npr. pojmi kot so naravno pravo, naravne pravice, ljudska suverenost ali obča volja praviloma sodijo $v$ domeno ideologije). $\vee$ strogem pomenu je mogoče po oceni istega avtorja le t.i. empirične koncepcije demokracije označiti za neideološke, medtem ko je med vsemi drugimi skupinami definicij mogoče opaziti ideološke 
Miro Cerar

Ideološki vidiki razmerja med

(demokratično) politiko in pravom

prvine. Le-te so $v$ nekaterih, sicer le redkih teorijah kot takšne izpostavljene $v$ tolikšni meri, da je na njihovi podlagi mogoče oblikovati posebno skupino ideoloških definicij demokracije. $\vee$ to skupino je npr. mogoče uvrstiti teorije, ki so jih razvili Bernard Williams, Herbert McClosky in Zevedei Barbu. Williams meni, da je ideologija prisotna ne le $v$ totalitarizmu, marveč tudi $v$ demokraciji, pri čemer je glavna razlika med obema le $\vee$ stopnji njene eksplicitnosti. McClosky ugotavlja, da demokracija sicer ne izpolnjuje $v$ celoti vseh zahtev, ki bi jo kvalificirali za ideologijo, vendar pa se tem zahtevam le približuje $v$ tolikšni meri, da jo je mogoče obravnavati kot ideologijo. Med doktrinarna vodila (tenets) demokratične ideologije avtor uvršča takšne koncepte kot so privolitev (consent), odgovornost, konstitucionalizem (limited or constitutional government), predstavništvo, večinsko načelo, pravice manjšine, načelo politične opozicije, svoboda misli, govora, tiska in združevanja, enake možnosti, religiozna strpnost, enakost pred zakonom, pravica do sodnega varstva in pravica do samoodločbe posameznika glede številnih osebnih zadev.

Med tremi omenjenimi tremi avtorji razvija Barbu najbolj abstraktno in široko ideološko pojmovanje demokracije, ob čemer po njegovem mnenju dejstvo, da demokracija ne more biti opisana kot posebna ideologija, še ne pomeni, da demokracija nima specifičnega ideološkega značaja. Nekatere ustaljene temeljne prvine pojma demokracije, kot so npr. ljudska suverenost, splošna volilna pravica ali večinsko načelo, šteje za vprašljive, saj so kot takšne lahko (in so tudi bile) instrumentalizirane tudi $\vee$ okviru totalitarnih režimov. Demokracijo nato Barbu definira $v$ smislu specifičnega miselnega okvira (democracy as a frame of mind), tj. $v$ smislu okvira določenih izkušenj, občutkov oziroma odnosov (attitudes), predsodkov in prepričanj, ki so skupni (shared by) vsem članom družbe ali vsaj njihovi veliki večini. Med takšne občutke oziroma prepričanja sodijo predvsem: a) občutek stalnega spreminjanja, pretočnosti in prilagajanja; b) občutek osebne udeleženosti $\vee$ politiki ter prepričanje, da je posameznik pozitiven dejavnik spremembe in soustvarjalec svoje lastne družbe; c) racionalni, individualizirani odnos do oblasti in priznanje njenega relativnega in predstavniškega značaja; d) zaupanje $v$ razum, ki pomeni sposobnost zagotavljanja reda $v$ hitro spreminjajočem se okolju (Rejai, 1967, str. 45-46).

\section{Ideološko pogojeni spektri političnih usmeritev}

Ker je ideologija prvenstveno političen fenomen, je tu pomembno opozoriti na različne politične usmeritve, ki se vzpostavljajo na ideoloških podlagah. Ideološka polarizacija se skozi politiko praviloma kaže $v$ razporeditvi volivcev, političnih strank in drugih političnih akterjev vzdolž t.i. osi desnica - levica. $V$ 


\section{Miro Cerar \\ Ideološki vidiki razmerja med (demokratično) politiko in pravom}

luči kompleksnega sodobnega političnega prostora sicer navedena os ni več v celoti ustrezen oziroma zadosten kazalnik pripadnosti posameznih političnih akterjev (npr. političnih strank) tej ali oni ideologiji ali politični usmeritvi, kajti v idejnih in akcijskih pogledih združujejo ti akterji $\vee$ sebi pogosto ideološkopolitične sestavine obeh omenjenih polov, seveda $v$ različnih kombinacijah in intenzivnostih. Kljub temu pa ostaja delitev na politično desnico in levico aktualna najmanj toliko, kolikor pomeni idealno - tipsko shemo, ki nam je $v$ oporo pri teoretičnem in praktičnem opredeljevanju in prepoznavanju različnih ideologij in politik.

$\checkmark$ okviru omenjene sheme se ideološko pogojene politične usmeritve od levega političnega pola proti desnemu kažejo $v$ naslednjih temeljnih kategorijah: radikalizem - liberalizem - zmernost (sredinskost) - konservativnost - reakcionarnost. Merila za uvrstitev $v$ eno izmed navedenih (tipskih) kategorij so seveda zelo raznolika, pri čemer je eno izmed najpomembnejših zagotovo posameznikov pogled na človekovo naravo (Baradat, 1997, str. 13). Predvsem pa je razlaga navedenih političnih kategorij močno pogojena z različnostjo pogledov na spremembe in na vrednote $v$ družbi. Če predvsem $v$ luči teh dveh vidikov oziroma konceptov strnjeno in nekoliko poenostavljeno povzamemo nekatere temeljne značilnosti vsake od navedenih kategorij, pridemo do naslednjih ugotovitev:

a) Radikalno politično usmeritev, ki sodi v skrajni levi pol političnega spektra, zagovarjajo ljudje, ki so izrazito nezadovoljni z obstoječim družbenim oziroma političnim stanjem. Želijo si takojšnje in korenite, tj. revolucionarne spremembe obstoječe ureditve, pri čemer zagovarjajo nekaj vrednostno in sistemsko novega in drugačnega (zavzemajo se npr. za dosledni ali »ekstremni« egalitarizem, radikalno zavračajo materializem ipd.).

b) Zagovorniki liberalne politične usmeritve so znatno manj nezadovoljni od radikalcev, vendar pa si vseeno želijo družbene oziroma politične spremembe. Liberalci v klasičnem pomenu se pri tem osredotočajo na posameznika in lastninsko pravico, sodobni liberalci pa ljudi upoštevajo tudi v kolektivnem smislu in poudarjajo (druge) človekove pravice, pri čemer je obojim, vsaj v pretežni meri, skupna vera $\vee$ dobroto ljudi, enakost, razum in pravo.

c) Zagovorniki zmerne (moderate) politične usmeritve, ki zavzema sredinsko mesto na osi med politično levico in desnico, v obstoječi družbi in politiki ne vidijo večjih slabosti, zato $v$ pretežni meri pristajajo na status quo. Ob tem seveda opažajo tudi možnosti za izboljšave obstoječega stanja na posameznih področjih, vendar pristajajo v zvezi s tem le na postopne in zmerne ukrepe, ki ne smejo bistveno spremeniti delovanja družbe. 
Miro Cerar

\section{Ideološki vidiki razmerja med}

(demokratično) politiko in pravom

d) Konservativna politična usmeritev sodi v desni politični pol, pri čemer so zagovorniki te usmeritve še bolj (in hkrati najbolj) zadržani do kakršnihkoli družbenih sprememb. Konservativna usmeritev je nekakšen antipod liberalni, saj se od le-te razlikuje v praktično vseh pogledih. Tako kot liberalci se tudi konservativci delijo na različne struje, pri čemer pa vsi praviloma izkazujejo nezaupanje $v$ človeško moralo in razum ter bodisi zanikajo ali pa vsaj zmanjšujejo pomen načela enakosti ljudi. Na splošno se konservativci nagibajo k veri, tradiciji, redu in ohranjanju obstoječih institucij.

e) Reakcionarna politična usmeritev zavrača moderne vrednote ter zahteva ponovno vzpostavitev političnega sistema in vrednot iz prejšnjega obdobja. Izmed vseh omenjenih političnih usmeritev je to edina, ki je v omenjenem smislu retrogradna, pri čemer obstoje tudi znotraj reakcionarnih pozicij različne stopnje intenzitete nezadovoljstva z obstoječim stanjem. Reakcionarji so $v$ vrednostnem pogledu na skrajnem desnem političnem polu (npr. zavračajo enakost ljudi in podpirajo razdelitev moči in bogastva na podlagi razlik $v$ rasi, družbenem sloju, inteligenci ipd.), vendar pa so $v$ svojem nezadovoljstvu z obstoječim ter $\vee$ želji po nagli in koreniti spremembi - kolikor ta časovni vidik opazujemo ločeno od vrednostnega -, zelo podobni radikalcem, ki se nahajajo na skrajnem levem političnem polu (tako so npr. $v$ tem pogledu skrajni marksisti na levici, ki menijo da je družbeno spremembo treba doseči po nasilni poti, podobni skrajnim fašistom na desnici, ki zagovarjajo vojno kot nekaj dobrega po sebi).

Navedene ideološko pogojene politične usmeritve so ključnega pomena tudi za pravo, oziroma za razmerje med pravom in politiko. Toda še preden preidemo $v$ zvezi s tem $k$ nekaterim splošnejšim ugotovitvam, si za ponazoritev velja pogledati, kako lahko ideološke oziroma politične usmeritve vplivajo na (pravno) odločanje posameznikov $\vee$ konkretnih primerih. Iz nekaj primerov, ki so predstavljeni neposredno $\vee$ nadaljevanju, so predvsem razvidne različne oziroma nasprotne ideološko-vrednostne ter posledično politične usmeritve. Pri tem je treba s "političnim« razumeti politiko $\vee$ najširšem smislu, torej ne le državno oziroma institucionalizirano politiko - politics, pač pa tudi "politiko" najrazličnejših individualnih in skupinskih vsakodnevnih odločitev - policy. Še posebej $\vee$ takšnem smislu je politika (policy) seveda tudi sestavina vsakodnevnega pravnega odločanja.

Če vzamemo za prvi primer prodajo zasebne nepremičnine (npr. hiše z zemljiščem) $\vee$ demokratični državi, $v$ kateri so deloma prisotni rasni predsodki (npr. ZDA), vidimo, da konservativci izrazito visoko vrednotijo lastninsko pravico, 


\section{Miro Cerar \\ Ideološki vidiki razmerja med (demokratično) politiko in pravom}

medtem ko liberalci zagovarjajo predvsem tudi druge temeljne oziroma človekove pravice in sicer $v$ drugačnem sorazmerju. $V$ takšnem primeru liberalec, kot prodajalec, ki je sam belec, med rasno različnimi kandidati za kupca, ki ponujajo enako kupnino, ne dela razlik. Vseeno mu je, ali proda zemljo in hišo belcu ali npr. črncu (Afroameričanu), saj $\vee$ moralnem oziroma temeljnem človeškem smislu med njima ne vidi oziroma ne dela razlik. Če v takšnem primeru Afroameričan ponudi višjo kupnino ali druge večje ugodnosti od drugih, potem ga bo prodajalec izbral za kupca svoje nepremičnine. Drugače je s konservativcem, belcem, ki meni, da lahko med kandidati za kupca povsem upravičeno zavrne pripadnika druge rase, npr. Afroameričana, čeprav ta za nakup nepremičnine ponuja enako ali celo bistveno več kot ostali. Konservativec pač $\checkmark$ tem primeru meni, da lahko to stori zato, ker gre za njegovo lastnino, s katero ima pravico razpolagati po lastni volji. Ob tem, da torej konservativec pripadnika druge rase vrednoti kot moralno oziroma človeško inferiornega $v$ razmerju do svoje rase, hkrati tudi lastninsko pravico vrednoti višje kot druge temeljne človekove pravice, zato meni, da lahko na takšni osnovi povsem upravičeno zavrne (diskriminira) pripadnika druge rase.

Podobno razliko $v$ vrednotenju opazimo pri vprašanju, ali sme lastnik ustreliti osebo, ki je vdrla $v$ njegov dom. Konservativec (npr. $v$ ZDA) na to odgovarja pritrdilno, če je to edini način za obrambo njegove lastnine. Liberalec pa meni, da nobena lastnina ni nikoli vredna toliko, da bi se smelo pri njeni obrambi tudi ubiti človeka ( $v$ tem primeru je odvzem življenja mogoč le, če gre hkrati tudi za silobran), zato se je treba $\vee$ takšnih primerih pač zanašati na policijsko zaščito, na povračila iz premoženjskega zavarovanja in druge manj drastične ukrepe.

Če si primeroma pogledamo še razliko $v$ vrednotenju pri vprašanju prostitucije, vidimo, da mnogi liberalci že na splošno takšnih dejanj, pri katerih žrtve ni mogoče neposredno identificirati (victimless crimes), praviloma ne želijo inkriminirati. Po njihovem mnenju je prostitucija sporazumno razmerje med dvema odraslima osebama, ki neposredno ne (pri)zadeva nikogar drugega, zato ga tudi ni treba uvrščati med kazniva ravnanja. Po drugi strani pa mnogi konservativci štejejo prostitucijo za moralno zavržno in zato vztrajajo, da se jo kot takšno pravno prepove oziroma inkriminira. Podobno npr. mnogi konservativci vztrajajo pri pravni prepovedi nepredpisane uporabe drog, medtem ko $\vee$ tem primeru mnogi liberalci menijo, da sta ustrezna vzgoja in zdravljenje uspešnejši zdravili kot pa policijska oziroma pravna intervencija.

Seveda je še nešteto drugih področij in posameznih vprašanj, glede katerih se politična levica in desnica zavzemata za bolj ali manj nasprotne rešitve. Med drugim gre za vprašanja, ki se nanašajo na homoseksualnost, abortus, evtanazijo, smrtno kazen, egalitarizem oziroma elitizem, (ne)diskriminacijo, enake možnosti, (inter)nacionalizem, lastnino, ekonomijo, družbeno solidarnost, socialo, popravo krivic, vrste in strogosti sankcij oziroma kazni za kazniva 
Miro Cerar

Ideološki vidiki razmerja med

(demokratično) politiko in pravom

in druga protipravna dejanja, kulturo, odnos med cerkvijo in državo itd. O vseh teh in drugih vprašanjih pa se odločitve $v$ pretežni meri sprejemajo in izvajajo prek prava, zato so seveda pravo in pravniki hote ali nehote vedno vpeti tudi $v$ dominantno ideološko-politično usmeritev določene družbe.

\section{Ideološki vidiki razmerja med demokratično politiko in pravom}

Ker namen tega prispevka ni na splošno prikazati in opredeliti razmerje med pravom in politiko (več o tem npr. Novak, 2003, str. 53-87; Cerar, 2001, str.15-46) ter podrobneje predstaviti njune sorodnosti in razlike (Cerar, 2004, str. 405-427), se v tem zadnjem delu osredotočamo predvsem na vprašanje, v kolikšni meri je pravo izraz določene politične ideologije in $v$ kolikšni meri lahko oziroma mora pravo (morebiti celo kot specifična, samosvoja ideologija) postavljati tudi meje politični ideologiji.

Na splošno je pravo po eni strani vedno izraz prevladujoče politične moči oziroma ideologije tistih družbenih skupin, ki ga $\vee$ pretežni meri določajo, po drugi strani pa se pravo, kot bolj ali manj avtonomna pojavnost, vedno vzpostavlja tudi kot lastna moč. Pravo je tako na eni strani oblika, skozi katero se izraža politična moč, na drugi strani pa je hkrati tudi relativno avtonomen družbeni dejavnik. Pri tem je avtonomna moč prava $\vee$ izrazito avtoritarni ali totalitarni politični ureditvi le minimalna oziroma zanemarljiva, kajti tu si politika podreja pravo $v$ vseh temeljnih (vrednostnih) normativnih in akcijskih vidikih, medtem ko je $\vee$ sodobni demokratični in pravni državi avtonomna moč prava relativno velika oziroma celo največja, če jo ocenjujemo v primerjavi z vlogo in avtonomno močjo prava $\vee$ nekdanjih družbah.

Seveda pa tudi $v$ demokratični ureditvi ne gre idealizirati avtonomne moči prava, kajti tudi $v$ takšni ureditvi je pravo $v$ temeljih determinirano in uokvirjeno z oblastno politiko. Zaradi že omenjenih značilnosti demokratične ideologije, ki je, kot je bilo pojasnjeno, bistveno manj javno izražena in strnjena kot to npr. velja za različne totalitarne ideologije, je seveda $v$ demokratičnem sistemu tudi težje zaznati ideološko-politično pogojenost pravne države, s katero lahko v širšem pomenu označimo integralni koncept in prakso prava $v$ sodobni demokratični državi (kot rečeno, mislimo pri tem na t.i. zahodni tip demokracije). Ugotovitev o težji prepoznavnosti ideološke narave prava oziroma pravne države velja še posebej za ljudi, ki sami živijo $\vee$ demokraciji in jo zato zaradi njene prevelike bližine, oziroma zaradi svoje vsakodnevne privajenosti nanjo, le stežka prepoznajo kot ideologijo. To je mnogo lažje ljudem iz nedemokratičnih okolij (npr. iz nekaterih ortodoksnih islamskih ali komunističnih držav), ki zahodno demokracijo 


\section{Miro Cerar \\ Ideološki vidiki razmerja med (demokratično) politiko in pravom}

dojemajo kot bistveno drugačno od njihove ureditve in jo zato - seveda pod močnim vplivom ideologije lastnega okolja - intenzivno doživljajo kot tujo ter pogosto celo kot sovražno ideologijo. Velja seveda tudi obratno.

Tudi Maihofer opredeljuje vlogo prava v razmerju do ideologije $v$ luči dveh nasprotujočih si temeljnih funkcij. Po eni strani opredeljuje pravo kot ideološki dejavnik (ideologisches Faktum), po drugi strani pa kot kritično instanco nasproti ideologiji (ideologiekritische Instanz) (Maihofer, 1969, str. 1-2). V prvem primeru je mogoče vlogo prava pojasniti v okviru tipičnih mišljenjskih modelov iz različnih obdobij - antike, renesanse in moderne - ki sporočajo, da pravo ni nič drugega, kot izraz in sredstvo oblasti močnejšega. Takšno sporočilo vsebujejo npr. naslednji trije tipi mišljenja: 1 . Pravo je tisto, kar koristi močnejšemu (ta pogled se prvič pojavi v Platonovih dialogih in se pripisuje sofistom, kot sta bila npr. Gorgias in Trazimah); 2. Pravo je orodje vladajočega posameznika vladarja (ta pogled je mogoče $v$ strnjeni obliki razbrati iz učenja Machiavellija); 3. Pravo je orodje vladajočega razreda (tu gre predvsem za Marxovo oziroma marksistično gledanje na pravo) (Maihofer, 1969, str. 1-8). Po drugi strani, tj. v smislu razumevanja prava kot dejavnika, ki se zoperstavlja ideologiji oziroma deluje od nje neodvisno, pa je mogoče po Maihoferju vlogo prava primeroma ponazoriti skozi naslednje tipe mišljenja:

1. Pravo je posrednik (Mittlere), ki posega $v$ družbeno konfliktna razmerja tako, da med ljudi sorazmerno oziroma pravično porazdeli družbene dobrine (takšen pogled na pravo se pripisuje že grškemu zakonodajalcu Solonu);

2. Pravo je sredina (Mitte) med obojestranskim preveč in premalo, kar je dejansko le specifična (Aristotelova) poglobitev prejšnjega pogleda, ki išče $v$ pravu pravično sredino pri razdeljevanju dobrin med določenimi osebami;

3. Pravo je posrednik med svobodo in varnostjo posameznika ter svobodo in varnostjo vseh drugih posameznikov (ta formalni princip, ki na specifičen način ponovno izraža idejo prava kot posredujočega dejavnika $v$ družbenih razmerjih, izhaja predvsem iz Kantove pravne filozofije) (Maihofer, 1969, str. 9-18).

$\checkmark$ vsaki od zgornjih funkcij se seveda skriva le delna resnica o naravi prava. Navedene umestitve prava $v$ okvir ideološke in antiideološke funkcije le potrjujejo, da ima pravo $v$ tem pogledu ambivalentno vlogo, saj je na eni strani izraz politične moči, na drugi strani pa predstavlja njeno omejitev. Ker je pravo tudi zgodovinska kategorija, je treba upoštevati, da se njegovi omenjeni vlogi v času in prostoru z različno stopnjo intenzivnosti izmenjujeta oziroma kombinirata. $V$ tem pogledu je prav demokratična politična ureditev tista, ki dopušča pravu, da se $v$ okviru svoje relativno visoke stopnje avtonomije vzpostavlja tudi kot specifična, samosvoja ideologija. To seveda ne pomeni, da je pravo kot takšno, tj. kot celoto, mogoče kakorkoli enačiti z ideologijo (podobno kot ideologije tudi ni 
Miro Cerar

Ideološki vidiki razmerja med

(demokratično) politiko in pravom

mogoče kar neposredno enačiti s politiko). Pravo kot celota je $v$ sodobnem modernem svetu izrazito obsežen in kompleksen sklop vrednostno prežetih pravnih načel, pravil in razmerij, ki sam po sebi teži prvenstveno k vlogi čim bolj objektivnega posrednika ali razsodnika pri urejanju oziroma reševanju potencialnih ali aktualnih družbenih konfliktov, iz česar je razvidno, da pravo kot takšno ne ustreza opredelitvi ideologije.

Po drugi strani pa se prav s formulo "pravna država" (Rechtsstaat, rule of law) v sodobnem času zelo pogosto uveljavlja specifična ideologija, in to predvsem takrat, ko se ta formula uporablja na deskriptivno in preskriptivno poenostavljen akcijski in motivacijski način. $V$ takšnih primerih se iz celote pojma pravne države izloča le posamezne prvine in funkcije prava in se jih nasproti javnosti (ljudstvu) predstavlja kot posebne ciljne vrednote. Kadar to počnejo politični akterji, gre za instrumentalizacijo prava oziroma pravne države $\vee$ politični namen. Dandanes se pri nas in $v$ demokratičnem svetu mnogi predstavniki političnih strank, državnih oblasti in nenazadnje mednarodnih institucij (npr. EU) sklicujejo na pravno državo $v$ najrazličnejših povezavah (kot ideal, ki ga bodo uresničili, če pridejo na oblast, kot šibko ali močno točko vladajoče politike, kot pogoj za sprejem kakšne države $v$ določene mednarodne organizacije itd.). Pri tem se v politični retoriki oziroma argumentaciji koncept pravne države izrazito poenostavlja in izraža predvsem $\vee$ zelo splošnih kategorijah reda, pravičnosti, človekovih pravic ipd. ter $\vee$ poudarjanju aktualnih in javno odmevnih pravnih dosežkov, ali pa, ravno obratno, $v$ kritičnem izpostavljanju aktualnih in javno odmevnih slabosti prava oziroma pravne prakse. Vse to je do neke mere neizogibni del demokratične "politične igre», pri čemer pa ima lahko pretirana politična manipulacija s pravom, in $v$ tem okviru predvsem tudi pretirana poenostavitev prava, zelo negativne posledice na delovanje in razvoj družbe, saj lahko javnost oziroma »ljudstvo " navda bodisi s pretiranim, nerealnim nezaupanjem ali pa s pretirano, nerealno vero $v$ pravo, kar vse slabi institucije pravne države in posredno tudi sámo demokracijo.

Prav tako pa lahko pravo v ideološkem smislu predstavlja in instrumentalizira tudi pravniški sloj (profesorji prava, sodniki, tožilci, odvetniki, notarji in pravniki v vseh drugih dejavnostih). Tudi v tem primeru ima ideološko predstavljanje pravne države vse zgoraj navedene lastnosti ideologije kot takšne, pri čemer pa služi v prvi vrsti uveljavljanju pomena prava kot posebne družbene vrednote. $\mathrm{Na}$ ta način se hote ali nehote varujejo poklicni položaji sloja pravnikov in vseh tistih, ki soodločajo $v$ pravnih procesih, pogosto pa je takšna avtonomna ideologizacija prava namenjena tudi izboljšanju institucionalnega in materialnega položaja pravnih akterjev. $\vee$ pravni retoriki oziroma pri argumentaciji takšne ideologizacije se pravni akterji najpogosteje načelno sklicujejo na družbeni pomen prava, na vrednoto zaupanja $v$ pravo, posebej pa izpostavljajo predvsem 


\section{Miro Cerar \\ Ideološki vidiki razmerja med (demokratično) politiko in pravom}

pomen različnih pravnih postopkov in pravic udeležencev $v$ njih ter pomen nemotenega delovanja poklicnih pravnih institucij (npr. pomen neodvisnosti sodstva, pomen ustreznih pravnih pogojev za učinkovitost pregona kaznivih ravnanj, pomen pravnega izobraževanja ali pomen različnih oblik pravne pomoči). Takšna avtonomna ideologizacija prava oziroma pravne države je vrednostno pozitivna in družbeno koristna, kolikor pripomore k splošnemu dviganju pravne zavesti ter $k$ izboljšanju delovanja pravnih institucij. Vrednostno negativna in družbeno destruktivna pa je takrat, kadar zasleduje le pretežno parcialne interese določenih pravniških slojev in tudi takrat, kadar prenapenja pomen, vlogo in zmožnosti prava pri urejanju družbenih odnosov in ustvarja s tem pri ljudeh glede prava nerealna pričakovanja. Še posebej vrednostno negativen pomen pa ima ideologizacija prava $\vee$ primerih, ko pravni akterji zavestno ravnajo politično (v smislu politike $v$ ožjem smislu - politics) in ne pravno. Primeri takšnega ravnanja so npr. politično motivirani (ustavno) sodni aktivizem, javno politiziranje tekočih sodnih in drugih pravnih postopkov ali politično pogojena korupcija, v katero so vpleteni pravni akterji (sodniki, tožilci itd.).

Za konec velja omeniti še Maihoferjevo misel, ki nam sporoča, da je pravi pravnik že po poklicu antiideolog. To misel velja razumeti predvsem kot pomembno napotilo za pravnikovo delovanje $\vee$ razmerju do zgoraj omenjenih vrednostno negativnih in $v$ tem okviru še posebej politično motiviranih primerov pravnikove ideologizacije prava. Hkrati pa se je treba zavedati, da se tudi sodobni pravnik nahaja $\vee$ ideološko pogojenem in obarvanem političnem in pravnem prostoru, ki neizogibno vpliva na njegovo delovanje. $\vee$ tem pogledu že ustavna in zakonska ureditev izpeljujeta določeno ideologijo (npr. pretežno liberalno ali konservativno), ki je $\vee$ demokratičnem okolju umeščena $v$ širši sklop demokratične ideologije in politike. Tudi pravnik je zato deloma že apriorno zavezan določeni ideologiji, ki jo nato pri ukvarjanju s konkretnimi primeri v dopustni meri dograjuje s svojim lastnim pravnim vrednotenjem. Predvsem v slednji domeni, tj. pri vsakodnevnem vrednostnem opredeljevanju $\vee$ okviru (normativne) konkretizacije splošnih pravnih norm in ustaljenih vodil pravne prakse, pa seveda pravnik $v$ svoje interpretacije in odločitve vnaša tudi duhá svoje osebne ideološke usmeritve, ne glede na to, ali in koliko se tega sploh zaveda. Izgradnja zavesti o ideoloških vidikih demokracije in prava ter prizadevanje za preprečevanje vrednostno in razvojno negativne ideologizacije prava (še posebej njegove politizacije), ostaja zato nenehna poklicna zaveza slehernega pravnika, vsakega pravnega akterja. 


\section{Miro Cerar \\ Ideološki vidiki razmerja med \\ (demokratično) politiko in pravom}

Dr. Miro Cerar je izredni profesor na Pravni fakulteti Univerze v Ljubljani in zunanji svetovalec za ustavna vprašanja v Državnem zboru Republike Slovenije. Je avtor treh knjig, $v$ domačih in tujih strokovnih revijah pa je objavil več člankov s področja teorije in filozofije prava ter ustavnega prava. Doslej je aktivno sodeloval na številnih domačih in tujih strokovnih in znanstvenih srečanjih.

\section{Literatura}

- Baradat P., L. (1997): „Political Ideologies«, Their Origins and Impact (Sixth Edition), Prentice Hall, New Jersey.

- Cerar, M. (2004): „Podobnosti in razlike med pravom in politiko«, v: X. Dnevi javnega prava (zbornik referatov), Portorož.

- Cerar, M. (2001): »Pravo in politika - vprašanje avtonomnosti modernega prava«, v: Pravo in politika, Liberalna akademija, Ljubljana.

- Coing, H. (1993): „Grundzüge der Rechtsphilosophie«, Walter de Gruyter, Berlin - New York.

- Della Porta, D. (2003): »Temelji politične znanosti«, Založba Sophia, Ljubljana.

- Drucker, H.M. (1974): „The Political Uses of Ideology«, The MacMillan Press Ltd., London.

- Eagleton, T. (1994): »ldeology and its Vicissitudes in Western Marxism«, v: Mapping Ideology, ed. Slavoj Žižek, Verso, London - New York.

- Grimes, A. (1980): »Ideology and Religion «, v: The Form of Ideology (Investigation into the sense of ideological reasoning with a view to giving an account of its place in political life), ed. Manning D.J., George Allen \& Unwin, London.

- Held, D. (1989): „Modeli demokracije«, Knjižna zbirka Krt, Ljubljana.

- Horn, N. (1996): "Einführung in die Rechtswissenschaft und Rechtsphilosophie», C.F.Müller Verlag, Heidelberg.

- Macpherson, C.B. (1973): „Democratic Theory: Essays in Retrieval«, Clarendon Press, Oxford, London.

- Maihofer, W. (1969): »Ideologie und Recht«, Vittorio Klostermann, Frankfurt am Main.

- Manning, D.J. (1980): »Introduction«, v: The Form of Ideology (Investigation into the sense of ideological reasoning with a view to giving an account of its place in political life), ed. Manning D.J., George Allen \& Unwin, London. 


\section{Miro Cerar \\ Ideološki vidiki razmerja med (demokratično) politiko in pravom}

- Novak, M.(2003): „Delitev oblasti: Medigra prava in politike«, Cankarjeva založba, Ljubljana.

- Rejai, M. (1967): „Democracy, The Contemporary Theories«, Atherton Press, New York.

- Ricoeur, P. (1981): „Hermeneutics and the human sciences, Essays on language, action and interpretation«, ed. J.B.Thompson, Cambridge University Press, Paris.

- Sartori, G. (1973): „Democratic Theory“, Greenwood Press, Westport, Connecticut.

- Tadić, L. (1988): „Nauka o politici«, Biblioteka Rad, Beograd.

- Vincent, A. (1995): „The Nature of Ideology«, v: Modern Political Ideologies, ed. A. Vincent, Blackwell, Oxford. 
Miro Cerar

Ideološki vidiki razmerja med

(demokratično) politiko in pravom

\section{SUMMARY}

\section{Ideological Aspects of the Relation Between (Democratic) Politics and the Law}

The concept of ideology originated in the 1790s in post-revolutionary France. It has been attributed to the French aristocrat, scholar and representative of the then materialistic philosophy Antoine Luis Claude Destutt de Tracy (1754-1836). Between 1796 and 1798, de Tracy coined the term "ideology" with the wish to create a new science that is a "science of ideas", within the framework of which ideas are created by means of knowledge based on empirical studies and not on supernatural or spiritual phenomena. In this original sense ideology is therefore a product of the modern age, the age of "enlightened reason", which is opposed to the old (medieval etc.) religious and other dogmas and rejects any kind of metaphysics and focuses on man's rational ability to identify the laws of the social world. Yet crucial differences can already be seen within the framework of the so-called classic use of the term ideology (de Tracy, Marx and Mannheim) regarding the assessment whether ideology can be objective. From their social scientific or philosophical points of view, Marx and Mannheim characterize and condemn ideology mainly as something particular and subjective. Such appraisals are also characteristic of modern definitions of the term ideology which differ yet recognize and emphasize the pluralism of ideologies in the search for the common denominators or fundamental characteristics of this term.

The common denominators of the term ideology especially include the following: 1) primarily the political significance of ideology; 2) descriptive and prescriptive nature (every ideology contains the interpretation of the present and anticipation of the future, taking into account the fact that the future is always presented as materially better than the present and, as a rule, in such a way that it would be possible to achieve it in the course of one man's life; 3 ) action and value-objective orientation; 4) orientation towards the masses; 5) simplification (schematic design) and presentation in the motivational spirit. Starting from the left of the political spectrum to the right, ideologically conditioned political orientations in the ideal-type form are shown in the following main categories: radicalism liberalism - moderateness - conservatism - reactionaryism. The criteria for the inclusion in one of the above-mentioned categories are, of course, highly diverse, one of the most important undoubtedly being the individual's view 
of the human nature. The interpretation of the above-mentioned political categories is greatly determined by the diversity of views of social changes and social values.

Within the framework of modern states and at the level of their mutual relations, there practically does not exist (any longer) any kind of long-term and institutionalised politics without an ideological basis. Therefore, the potential assumption that modern democracy does not have a leading or dominant ideological basis is wrong. Any given kind of democracy is designed on a given common, uniform and dominant ideological basis (in this sense, its politics and the law also share its faith) which, however, is not manifested in the same way and to the same extent as is the case with the ideologies of different "revolutionary" or "totalitarian" non-democratic societies. The ideology of the modern Western type of democracy is generally not expressed in a concentrated manner, for instance at regular and "compulsory" public political marches, in everyday public political proclamations, in the form of striking ideological mottos and appeals for some kind of joint action etc. In its common denominators, the democratic ideology is mainly manifested in a dispersed manner and as such in a less transparent manner than the non-democratic ideology. Of course, in the modern information society, ideology as such is also highly penetrating as it, through different information media and educational institutions, reaches nearly everyone, while on the other ideology as such, i.e. as unconcentrated, does not arouse the feeling in people that they are under ideological influence or pressure.

On one hand, the law is always a reflection of the dominant political power and ideology, while on the other, the law as more or less autonomous phenomenon always establishes itself as its own power. The law is therefore, a form through which political power is expressed, as well as a relatively autonomous social factor. The autonomous power of the law in the explicitly authoritarian or totalitarian political constitution is only minimal or negligible because here politics subjects the law to itself in all fundamental (value) normative and action aspects, while in the modern democratic state governed by the rule of law the autonomous power of law is relatively great or even the greatest if we assess it in comparison to the role and autonomous power of law in pre-modern societies. Likewise, one cannot idealize the autonomous power of law in a democratic constitution because in such constitution the law is also fundamentally determined by authority politics. 
Miro Cerar

Ideološki vidiki razmerja med

(demokratično) politiko in pravom

The democratic political constitution allows the law to establish itself as a specific and independent ideology within the framework of its own relatively high degree of autonomy. This, of course, does not imply that the law as such, i.e. as a whole, can be equated with ideology (similarly, ideology cannot be directly equated with politics). The law as a whole is in our modern world an explicitly extensive and complex assembly of value-permeated legal principles, rules and relations which primarily strives to play, as much as possible, the role of objective intermediary or arbitrator in the settling or solving of potential or current social conflicts. It can therefore be concluded that the law as such does not fit the definition of ideology. On the other hand, it is precisely through the "rule of law" formula ("Rechtsstaat") that specific ideology is very often gaining ground in modern times, especially when this formula is used in a descriptively and prescriptively simplified action and motivational manner. In such cases only individual elements and functions of the law are extracted from the entire concept of the "rule of law" and presented as special target values against the public (population). When this is done by political actors, we are dealing with the instrumentalisation of the law and the rule of law for political purposes. In such cases the concept of the rule of law is explicitly simplified in political rhetoric and argumentation and is mainly expressed in very general categories of order, justice, human rights etc. and by emphasizing current and publicly known achievements of the law, or, vice versa, by critically exposing current and publicly emphasized shortcomings of the law or legal practice. All this is, to a certain extent, an inevitable part of the democratic "political game", in which exaggerated political manipulation of the law and in this framework also exaggerated simplification of law can have quite negative consequences on the functioning and development of the society because it can fill the public or the "population" with either exaggerated (unreal) distrust or exaggerated (unreal) faith in the law, which altogether weakens the institutions of the state governed by the rule of law and, indirectly, the democracy itself.

The law may also be ideologized and instrumentalized by the stratum of professional lawyers. Also in this case, the ideological presentation of the state governed by the rule of law has all the above-mentioned characteristics of the ideology as such, while being primarily used for the affirmation of the significance of the law as the special social value. By doing 
so (intentionally or unintentionally), occupational positions of the stratum of lawyers and all those who co-decide in legal processes are protected, and often the objective of such "autonomous ideologisation of the law" is the improvement of institutional and material status of professional legal actors. When justifying such ideologisation, legal actors most commonly refer to the social significance of the law, the value of confidence in the law, and especially emphasize the meaning of different legal processes and rights of their participants and the importance of smooth operation of professional legal institutions. "The autonomous ideologisation of the law" is, with regard to the value, positive and socially beneficial insofar as it contributes to the general legal awareness raising and to the improvement of legal institutions' operation. It is negative with regard to the value and socially destructive when it follows only partial interests of certain lawyers' strata and also when it overly stresses the meaning, role and capacity of the law in the regulation of social relations and, by doing so, creates unreal expectations with regard to the law in people. The ideologisation of the law by legal actors has a particularly negative meaning with regard to the value in the case when these actors wilfully act politically (in terms of politics in the narrow sense of the word) and not legally. The examples of such conduct include politically motivated (constitutional) judicial activism, public politisation of current judicial and other legal procedures or politically motivated corruption which involves legal actors (judges, prosecutors, lawyers etc.). 